\section{Japan as a Source of Legal Ideas: A View from the Mekong Subregion of ASEAN}

\section{NOBUMICHI TERAMURA}

University of Brunei Darussalam and The University of Sydney

\section{ABSTRACT}

Much has been written about Japanese law within the context of Japan. Less is known about the application of Japanese legal models outside Japan. A prevailing view among some commentators is that Japanese law scholarship does not offer insights that are useful beyond Japan-based legal studies. Other scholars challenge this perception by invoking Japan's legal development aid projects in the Mekong subregion of ASEAN-especially in Vietnam, Cambodia and Laos. These projects have been in operation for over twenty years and aim to foster the economic growth of host countries. This article aligns with the view that Japanese law exists beyond, and is influential outside, Japan. It calls for further action by legal specialists to reexamine and re-assess the corresponding influence of Japanese positive law in these countries, both in improving the transparency of those legal systems and enhancing communication among local, comparative and Japanese law experts.

\section{KEYWORDS}

ASEAN; Asian law; Cambodia; comparative law; COVID-19; economics; international relations; Japanese law; JICA; Laos; law; legal technical assistance; Southeast Asia; Vietnam
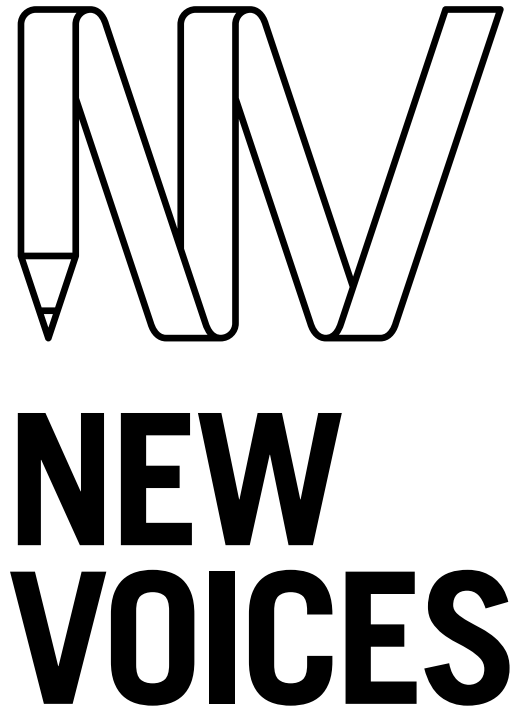

IN JAPANESE STUDIES

JAPANFOUNDATION \& BRINGING JAPAN TO YOU

To link to this article: https://doi.org/10.21159/nvjs.13.02

ISSN 2205-3166

New Voices in Japanese Studies is an interdisciplinary, peer-reviewed journal showcasing the work of emerging scholars with ties to Australia or New Zealand and research interests in Japan.

All articles can be downloaded free at newvoices.org.au

(c) The Japan Foundation, Sydney and Nobumichi Teramura, 2021

\section{(c) (i) $(9)$}

This work is licensed under a Creative Commons Attribution-NonCommercialNoDerivatives 4.0 International License. 


\section{INTRODUCTION}

$\mathrm{J}$

apanese law has been the subject of research for over a century by non-

Japanese scholars and lawyers, both because of its important status in comparative legal studies, and as a consequence of interest in particular aspects of Japanese culture and society and Japan's strong economy. ${ }^{1}$ Scholars within the field have long been self-aware about the factors that influence interest in Japanese law (e.g. Beer and Tomatsu 1978, 2-5; Haley 2010; Ginsburg 2010). However, Japanese law has less often been perceived as a source of legal thinking with application outside Japan (see Taylor 2001). Quite a few commentators see Japan as a successful example of legal transplantation based on Western models, such as the legal systems of Germany, France and the US (Graziadei 2019; Siems 2019, 865), and are drawn to the specific institutions, culture and environment of Japan, and by extension see its experience as inapplicable to other countries (e.g., Givens 2013; Colombo 2014). ${ }^{2}$ To the extent that they see Japan as a source of legal influence, their primary focus tends to be on its dissemination of a modern German-style legal system to its neighbouring countries, and not on how Japanese law itself has influenced legal thought in those countries (Lei 2012; Kischel 2019, 55, 689, 699, 728-35). This confinement of Japanese law and legal institutions to Japan's domestic sphere by scholars writing in English is curious because over the last five decades Japan has become both an influential and sizeable provider of official development assistance (ODA) internationally-including significant programs of legal technical assistance in Asia.

In the last decade, however, we have seen a new stream of scholarship that focusses on Japan's role in the modernisation of legal systems in the Association of Southeast Asian Nations (ASEAN). Taylor has suggested that reviewing Japan's legal technical assistance since the mid-1990s in Southeast Asia is important (Taylor 2001) because it reveals "ongoing tension between a western/globalized vision of rule-of-law assistance and the political imperatives at the national/local level" (Taylor 2009, 164). Taylor's thesis anticipates the need to assess the impact of Japanese positive law in a recent hotspot for comparative legal studies: the Mekong subregion of ASEAN. ${ }^{3}$ Tamura (2019), meanwhile, reminds us that Japanese contributions to modernising law in Southeast Asia are not new: Dr Tokichi Masao-a prominent Japanese jurist and the General Legal Adviser to the Kingdom of Siam-made a significant contribution to the codification of civil laws in Thailand in the early 20th century (54-55). Tamura also refers to how Thai commissioners drafted the 1925 Revised Civil and Commercial Code of the

\footnotetext{
* First and foremost, the author would like to thank Professor Veronica Taylor of Australian National University for her thoughtful guidance and comments that helped take the article to the next level. The author also acknowledges his enormous debt to Ms Elicia O'Reilly, the Series Editor of NVJS, who has patiently provided the author assistance to improve the manuscript until the very end. Moreover, the author is grateful for various comments and feedback from many individuals such as Dr Gwyn McClelland, anonymous reviewers and Professor Luke Nottage. Of course, responsibility for any errors in the resulting work remains my own. 1 See generally The Australian Network for Japanese Law (ANJeL)'s bibliography on Japanese law research, available at: https://www.anjel.com.au/research. See also the bibliography on 'Gender and Law Scholarship in the Law in Japan Field' (Levin and Hiraoka 2020).

2 Legal transplantation means "the moving of a rule or a system of law from one country to another" (Watson 1974, 21). See also Section 5.1 below.

3 The Mekong subregion comprises Vietnam, Cambodia, Laos, Myanmar and Thailand (Ho and

Pitakdumrongkit 2019).
} 
Kingdom of Siam, using the Japanese Civil Code as the foundation for their reception of the German Civil Code $(2019,57 \mathrm{ff}) .{ }^{4}$

Since before the COVID-19 pandemic, the Mekong subregion had been gaining new economic prominence as multinational enterprises have been increasingly relocating their factories from China to countries along the Mekong River such as Vietnam, Cambodia and Laos (Teramura et al. 2021, 356). They have done so, of course, in the shadow of US-China geopolitical and economic tensions. As a result, increased global attention has been focusing on their growing economies and developing legal systems (e.g., Arcibal 2021; Walsh et al. 2021). This trend accelerated following the emergence of the pandemic, as the Mekong subregion remained (at least in the early stages of the crisis) relatively COVID-free (Dahles 2020; Teramura et al. 2021, 356).

Japan's national ODA agency, the Japan International Cooperation Agency (hereafter, JICA), has had a presence in the Mekong subregion since the 1990s. JICA is an independent administrative institution under Japan's Ministry of Foreign Affairs (MOFA) with decades of experience in the modernisation of law in the Mekong subregion through its legal technical assistance projects (Kitagawa 2006, 254-56; JICA 2014; Nottage 2019a, 204-07). For many of the countries hosting legal technical assistance projects, JICA has been the most influential foreign donor and development partner. In particular, the private law frameworks of Vietnam, Cambodia and Laos have been heavily influenced by Japanese legal advice provided through JICA projects (Kaneko 2019, 155; JICA 2014, 5-6). ${ }^{5}$ One consequence of this is that Japanese legal concepts and design have influenced the private law of those countries to a much greater extent than is generally understood, as discussed in Section 3 below.

This article seeks to draw more attention to the role of Japanese law as a source of legal ideas and infrastructure in Vietnam, Cambodia and Laos, particularly in the context of their growing importance for economic activity in the pandemic era. It explains how Japanese law has shaped the private law of these countries, using Cambodia as an example. It argues that recognising the influence of Japanese law in these jurisdictions can benefit legal scholarship, particularly in comparative law, and calls for further work to critically examine and analyse the influence of Japanese law in these countries. The implication of this is the potential to shift the idea of Japanese law as confined to the Japanese archipelago.

\section{EXTENDING JAPAN'S REACH THROUGH LEGAL TECHNICAL ASSISTANCE}

JICA was established in Japan in 1974 with the mission to work on human security and quality growth under the Development Cooperation Charter, a 
foundation of Japan's ODA policy (JICA 2009; MOFA 2015). ${ }^{6}$ As with other development agencies, JICA's focus for many years was on the creation of physical infrastructure in developing countries (Lancaster 2010, 29, 34). However, it changed its direction in the 1990s when Japan's ODA flows shifted more toward soft infrastructure such as education and law (Taylor 2005, 255). JICA commenced its legal technical assistance projects in 1994, initially in response to a request from the Vietnamese government to support its law reforms for the Doi Moi (renovation) policy, which introduced a marketoriented economy to Vietnam (ICD 2020, 7, 10). As of July 2021, eleven Asian countries have asked the Japanese government for legal technical assistance, and their governments have recently been working closely with JICA on various law reform projects amid the COVID-19 pandemic. ${ }^{7}$

Japan's legal technical assistance projects have been conducted through JICA as part of its broader portfolio of technical cooperation projects, which cover education, governance, health, disaster management, peacebuilding, gender and poverty reduction, among other areas. ${ }^{8}$ Japanese legal technical assistance involves JICA's parent ministry (MOFA) and other Japanese government institutions and ministries including the Ministry of Justice (MOJ), through its International Cooperation Department (ICD) and its satellite organisation, the International Civil and Commercial Law Centre (ICCLC), as well as the Supreme Court, Public Prosecutor's Office, the Japan Federation of Bar Associations (Nichibenren), the Japanese Federation of Industries (Keidanren) and Japanese university law faculties (Taylor 2005, 261; ICD 2020, 2).

For JICA, the primary rationale for legal technical assistance projects has been that a well-designed legal system is essential for economic development (Yamada 2001). Thus, the immediate aim of the projects has typically been to help countries improve their legal systems as a way of transitioning to a market economy, by supporting: (i) the drafting of basic laws; (ii) the establishment of judicial institutions for the operation of enacted laws; and (iii) the capacitybuilding of legal professionals (ICD 2020,3). The long-term goal of these projects, as stated by the Cabinet of Japan and ICD, is to assist host countries in achieving quality growth based on the rule of law and protection of human rights (MOFA 2015, 6; ICD 2020, 5).

Despite these aspirational aims, external evaluation of the projects has been mixed. On one hand, their respect for local ownership and partnership with host countries has been positively evaluated (Nicholson and Hinderling 2013, 304, 308; Kuong 2018, 285). This reflects the Development Cooperation Charter's emphasis on recognising the host states' sovereignty and self-help

6 The Cabinet of Japan determined the Charter in 1992, and later revised it in 2003 and 2015 (see MOFA 1992; 2003 ; 2015). The origin of JICA and Japan's ODA may trace back to the start of the Japanese government's affiliation with the Colombo Plan for Cooperative Economic and Social Development in Asia and the Pacific in 1954 (MOFA 1994).

7 Respectively, these countries are Vietnam, Cambodia, Laos, Indonesia, Uzbekistan, Mongolia, China, 
efforts. ${ }^{9}$ On the other hand, one consequence of such a level of respect is that Japan did not emphasise rule-of-law principles in its legal aid in the early days of the legal technical assistance projects, and this could be considered a weakness in its programming (see MOFA 1992; 2003). Some commentators perceive this approach as representing Japan's "lack of advocacy for substantive or thick rule of law principles" (Nicholson and Kuong 2014, 174). Others, however, point out that a lack of rule-of-law ideology is actually useful because it enables transitioning countries to undertake market-strengthening legal reforms without "complicating normative constraints such as a focus on human rights or democratic reform" (Taylor 2005, 269)..$^{10}$ This observation is still salient, considering that Vietnam and Laos are formally socialist singleparty states, and Cambodia is a de-facto single-party state. ${ }^{11}$

As Nicholson and Hinderling (2013) succinctly put it, rule-of-law promotion itself has been the subject of diverse critiques, including: "its ethnocentricity; whether it sufficiently admits context; whether it admits and works with the plurality of legal systems; its colonial roots; its portability and whether it has a positive impact on either economic growth or delivery of democratisation/ human rights" (275). Presumably these criticisms, and other geopolitical and historical considerations such as Japan's own wartime and colonial history, made Japan hesitant to prioritise rule-of-law promotion or even use the term 'rule of law' in the early years of the legal technical assistance projects (Kuong 2018, 274-76). Japan's 2003 ODA Charter, for example, included no mention of 'rule of law', although it features prominently in the 2015 version of the Charter. ${ }^{12}$ While experts agree that Japan has progressively engaged in the debate about the place of rule-of-law promotion in aid projects (Taylor 2005; Kuong 2018; Nicholson and Hinderling 2013; Nicholson and Low 2013; Nicholson and Kuong 2014), it is an imprecise instrument for judging the ultimate value of Japan's legal technical assistance projects. ${ }^{13}$

To date, a significant number of codes and laws have been established or reformed in host countries through the legal technical assistance projects, with support from JICA and other government bodies. In particular, the outcomes of the legal technical assistance projects in Vietnam, Cambodia and Laos are arguably outstanding in terms of their scope and comprehensiveness.

9 For example, the revised 2015 Charter provides: "In its development cooperation, Japan has maintained the spirit of jointly creating things that suit partner countries while respecting ownership, intentions and intrinsic characteristics of the country concerned based on a field-oriented approach through dialogue and collaboration. It has also maintained the approach of building reciprocal relationships with developing countries in which both sides learn from each other and grow and develop together. These are some of the good traditions of Japan's cooperation which have supported self-help efforts of developing countries and aimed at future self-reliant development" (MOFA 2015, 4).

10 Some commentators go even further, suggesting that economic self-interest is the major critical motivating factor for Japan's (and also other donors') foreign aid policies (Schraeder et al. 1998). However, it is unclear whether this argument targets the legal technical assistance projects.

11 See Article 4 of the Constitution of the Socialist Republic of Vietnam and Article 3 of the Constitution of the Lao People's Democratic Republic. The Constitution of the Kingdom of Cambodia stipulates in its preamble that the country is to be a multi-party liberal democratic regime. However, Cambodian People's Party (CPP) has been in power since 1979 and currently holds every seat in the legislature (Reuters Staff 2020).

12 The 2015 Development Cooperation Charter refers to 'rule of law' in multiple instances (MOFA 2015, 2, 6, 8, $10,15)$.

13 Host countries are similarly divided on this point. For example, in one study, several local interviewees from Vietnam praised JICA for its politically neutral approach and for not strongly advocating judicial independence and the rule of law (Nicholson and Low 2013, 27). In contrast, some Vietnamese experts have criticised JICA for focusing on "technical assistance" only and not pursuing "an idea" (Nicholson and Kuong 2014, 174). Cambodian interviewees were similarly divided on this issue (Nicholson and Low 2013; Nicholson and Kuong 2014). 
Focusing mainly on private law, in Vietnam alone the projects have assisted in drafting and reforming the 1995, 2005 and 2015 Civil Codes, the 2004 and 2015 Civil Procedure Codes, the 2008 and 2014 Civil Judgement Execution Laws, and the 2004 and 2014 Bankruptcy Laws. Further, they contributed the drafting and reform of the 2007 Civil Code and 2006 Civil Procedure Code in Cambodia, as well as the 2018 Civil Code in Laos, among other initiatives (ICD 2020, 6-7). ${ }^{14}$ The implication of these reforms is that day-to-day transactions taking place in these jurisdictions are now regulated by legal norms which were established with Japanese law experts' support.

\section{THE PRACTICAL SIGNIFICANCE OF JAPAN'S LEGAL TECHNICAL ASSISTANCE PROJECTS}

One practical result of Japan's sustained engagement in legal reform is that Japanese legal ideas now arguably form part of the legal pluralism in countries that are important targets for foreign investment and legal practice. The following section considers the economic background against which the projects have been conducted in Vietnam, Cambodia and Laos and then gives a worked example of how a Cambodian project unfolded, and with what results.

\subsection{Economic Resilience in the Face of the COVID-19 Pandemic}

The economic growth of Vietnam in the last 30 years has been striking and continues apace, even in the face of a pandemic. From 1990 to 2019, the country's gross domestic product (GDP) increased from 6.5 billion to 262 billion USD, with an average annual growth rate of 6.8\% (World Bank 2021d). The COVID-19 pandemic has more recently hit Vietnam hard, but it is one of the few economies where a recession is not expected, in view of a GDP growth rate of $2.9 \%$ in 2020 (World Bank 2021c). The country's economic resilience can be explained by the behaviour of its domestic economy and its external sector (World Bank 2020, xi). The domestic economy has so far managed to avoid a serious slump, thanks to its success in containing the spread of the virus (World Bank 2020, xii; Duong 2020a, 2020b). As at 5 July 2021, the number of confirmed cases in Vietnam remains comparatively low, having just surpassed 28,470, and the number of related deaths is also low, at 146 (WHO 2021d). ${ }^{15}$ Mobility restrictions were eased at least in the early stages of the pandemic, so their impact on domestic consumption was significant but not fatal (World Bank 2020, xii; Leung 2020). The external sector has been performing well because of export demand and foreign investment (World Bank 2020, xii), which the restructuring of global supply chains has reinforced since the beginning of the US-China trade war and (ironically) the pandemic (Reed 2020; Boudreau and Nguyen 2020). ${ }^{16}$ Hence, international businesses have been eyeing Vietnam as an emerging manufacturing hub, with rising expectations underpinned by the country's vast network of free trade agreements (FTAs).

14 For further detail on legal and judicial development projects in Cambodia, see Teramura (2021).

15 In comparison, Australia had recorded a total of 30,610 COVID-19 cases and 910 deaths as at 30 June 2021 (Department of Health 2021).

16 The early stages of the US-China trade war were marked by the imposition of tariffs on Chinese goods by the Trump administration. Tensions continue under the Biden administration, "extend[ing] beyond trade to encompass a range of geopolitical and human rights issues" and with tariffs largely remaining (Zhou 2021). 
Cambodia's economy, while harder hit by COVID-19, is also promising. From 2000 to 2019, the country's GDP increased from 5.2 billion to 27 billion USD, with an average annual growth rate of $7.7 \%$ (World Bank 2021d). It managed to curb the first outbreak of COVID 19, as demonstrated in its small volume of cases as of 19 March 2021-1,541 confirmed cases and one death (WHO 2021b). This success was thanks to its effective initial response strategy, including aggressive testing, contract tracing, travel restrictions and school closures (Chheng 2020). Unfortunately, the number of cases later surged to 59,978 confirmed cases and 881 deaths (as at 5 July 2021) during the second wave (WHO 2021a), forcing the country's densely populated areas to implement further restriction measures in 2021 (Post Staff 2021). Moreover, the virus plunged the country's economy into a recession with registered negative GDP growth of minus 3.1\% (World Bank 2021a). The garment industry, the country's growth engine, was severely hit by supply chain disruption in China and the cancellation of orders from the European Union (EU) and the US due to the pandemic (Chheng 2020). Another economic engine, the tourism sector, has also been hurt severely due to domestic and international travel restrictions (Chheng 2020). However, opportunities are evident for Cambodia to achieve a rapid and robust recovery as the country has the potential to become a hub for global supply chain restructuring (Master et al. 2018).

The country is attractive to investors because of its openness to trade, as well as its liberal economic policies, social stability, growth potential and competitive labour costs (KPMG 2020; Swiss Re Institute 2020). Losing preferential access to the EU market can be a disadvantage (see European Commission 2020), but the loss may be leveraged by the surplus from the Cambodia-China FTA offering Cambodia preferential access to China's rapidly recovered domestic market (Thul 2020; Elliot 2021). Moreover, the US-China trade war may help Cambodia elevate its position in the global value chain, as its strong relationship with China may attract Chinese and other factories to its shores for exporting goods and items from Cambodia to the rest of the world (Phea 2020; Primiano and Po 2020). If Cambodia is able to overcome its alleged legacy problems such as lower productivity, expensive electricity and unofficial fees, and adapt technological innovations (Amarthalingam 2020) in addition to the challenges of COVID-19, the country has the potential to lead the global economy in the virus-economy recovery race.

Finally, Laos likewise has strong growth potential. The country increased its GDP from 1.7 billion to 18 billion USD between 2000 and 2019, recording an average annual growth rate of 7\% (World Bank 2021d). The year 2020 was indeed a challenge for Laos as its economic growth declined to an estimated minus $0.4 \%$ (World Bank 2021b), despite the country's low number of COVID-19 cases-2,630 confirmed cases and three deaths as at 5 July 2021 (WHO 2021c). Lockdown measures hit the service sector hard, remittances dried up and the unemployment rate rose to 23\% (World Bank 2021b). Nevertheless, there are some positive factors. The country maintains political and social stability, low labour costs, liberal economic policies and an extensive FTA network, which are advantages (OECD 2017). Due to its close ties with China and its participation in the Belt and Road Initiative (BRI), its infrastructure has been improving (Sims 2020; Keola 2021). The country's 
lengthy borders with China, Thailand, Vietnam, Cambodia and Myanmar may also help it to integrate with these larger economies. The factors discussed above have the potential to make Laos a legitimate low-cost export base from which to sell goods within the region and beyond, for manufacturers seeking to diversify from existing production bases in China, Thailand and Vietnam (US Department of State 2020b).

\subsection{Japanese Law as Part of Legal Pluralism: Cambodia}

In Cambodia, JICA has been conducting a 'Legal and Judicial Development Project' since 1996 (MOJ 2021). One achievement of the project is the promulgation of the 2007 Civil Code, whose drafting process demonstrates how Japanese legal ideas became integral parts of the country's foundational law. In the drafting process, a group of leading Japanese legal scholars-the Working Group (WG) for the Cambodian Civil Code-played a vital role (Morishima 2003, 7). First, they prepared a detailed proposal of the new Civil Code based on the Japanese Civil Code and civil laws of other countries such as Germany and France. This is because Cambodia had no existing codified civil law that could be used as a basis of the new Code, due to the atrocities of the Khmer Rouge period (Sakano 2021, 57). Second, they explained the proposal face-to-face to the Study Group (SG) for the Cambodian Civil Code that was established within the Ministry of Justice of Cambodia, to obtain feedback from Cambodian legal elites. Third, they drafted the Civil Code in Japanese, based on comments of Japanese and Cambodian experts. The draft Civil Code was then translated by the Cambodian SG into Khmer, with the support of JICA staff who were fluent in Khmer (Sakano 2003).

The extended commitment of Japanese law experts underpins the pervasive influence of Japanese legal thinking on the Cambodian Civil Code. We can analogise this to the process of transmitting legal knowledge and ideas through interactions between legal academics and students in a legal education setting, where some commentators suggest that "[1]aw school curricula provide a framework not only for academic studies, but also for the student's construction and interpretation of the intellectual and ethical parameters of the law" (Ross et al. 2016, 70). In other words, what law lecturers teach students affects the latter's consideration of the law.

Thinking about this in relation to JICA's legal technical assistance project in Cambodia suggests two levels at which Japanese legal advisors may have exerted influence over the Cambodian Civil Code. The first layer was produced by the WG, consisting of senior Japanese law professors who were trained and educated in the world of Nihon-hō [日本法; 'Japanese law'] (Morishima 2003, 7; Sono 2001; see also Section 4.1 below). That the WG prepared the proposal and drafts of the Civil Code inevitably means that these documents reflected legal thinking developed by Japanese scholars who were driven by and attached to Japanese legal ideas. The second layer was created by the SG, formed by elite Cambodian lawyers. The SG commented on and translated the proposal and the drafts of the Code under the guidance of the Japanese law experts. By that we can understand that the Cambodian experts reviewed 
and modified the draft Code, consciously or unconsciously drawing on the legal thoughts recommended by the Japanese law professors. In practice, the Japanese law scholars reported that they considered approaches from various legal systems, apart from those of Cambodia and Japan. However, we also know that Japanese legal academics are prone to evaluate non-Japanese legal systems through 'Japanese' lenses that are distinct and rarely adopted in the outside world (Sono 2001, 56-58). As a result, the doctrinal—or what lawyers sometimes call 'black letter law'- contribution of the Japanese Civil Code to the Cambodian Civil Code is physically manifested in the commentary found in various official documents, such as in the unpublished Japaneselanguage commentary on the Cambodian Civil Code, which explicitly states which provisions of the Code are based on which corresponding articles of the Japanese Civil Code. ${ }^{17}$

This example of Japanese-influenced Civil Code reform in Cambodia is not an isolated one. In Cambodia, similar law reform approaches have been taken to establish the Civil Procedure Code and other laws (Takeshita 2003), due to the serious lack of human resources in the legal sector caused by the civil war (Phallack 2012, 8). In Laos, an Advisory Group consisting of professors from top Japanese law schools guided the preparation of 2018 Civil Code (Irie 2020, 65ff). In Vietnam, recommendations from leading Japanese law experts led to reforms and revisions of various aspects of the Civil and Civil Procedure Codes (Kawashima 2019; Kaneko 2019). Thus, Japanese legal models are part of the legal pluralism among the countries along the Mekong River.

\section{3 (Re-JAssessing the Influence of Japanese Law in Vietnam, Cambodia and Laos}

Despite the extensive work by Japanese legal experts assisting Vietnam, Cambodia and Laos in drafting and revising their main bodies of private law over 20 years in the ways outlined in Sections 2 and 3.2 above, a general perception exists among (mainly western) government officials and international legal experts that these countries continue to be influenced primarily by French and Soviet civil law traditions deriving from their colonial and Cold War experiences. ${ }^{18}$ We could view these perceptions as postcolonial stereotypes used by international institutions, or as ways of casting these states as having limited legal certainty and a weak rule of law. ${ }^{19}$ These perceptions impose an arguably unwarranted reputational cost on countries seeking to attract international investment of the kind that may enhance the further economic growth of Southeast Asia (West and Leong 2019, 65-67).

Part of the reason for the persistence of outdated perceptions about the doctrinal legal architecture in these economies is most likely due to a lag 
in legal scholarship that delivers sufficiently detailed analysis of both the current private laws of those countries and how they operate in practice. Certainly, law and development scholars have researched the legal technical assistance projects delivered along the Mekong River, focusing on the projects' methodological and theoretical aspects (see Section 2 above). These include a comparison of Japan's projects with the agendas of other donors (Taylor 2005; Nicholson and Hinderling 2013; Nicholson and Kuong 2014); local experiences of court-oriented law reform guided by JICA and other international donors (Nicholson and Low 2013); project implementation in host countries (Kaneko 2010; Kuong 2018; Kaneko 2019); and Japan's evolving experience as a rule-oflaw donor (Taylor 2012). However, what these otherwise valuable contributions do not do is to delineate the contour of Japanese legal influence in a way that is useful for international businesses and lawyers needing to understand the positive law of Vietnam, Cambodia and Laos (see Section 1).

Notably, one barrier to communicating legal transformation in the subregion is a linguistic one. Most of the resources related to Japan's legal technical assistance projects and their end products are available only in Japanese and local languages (Teramura 2021). ${ }^{20}$ Official commentaries and certain textbooks on the Cambodian Civil Code and Civil Procedure Code are written only in Khmer and Japanese (JICA n.d.). Many Japanese academics, some of whom have worked as advisors for JICA and ICD, have authored research contributions on the projects-but again, these are only available in Japanese. ${ }^{21}$ This is legitimate for these kinds of projects, most of which have modest budgets, especially considering their scale (Nicholson and Kuong 2014), and that they are delivered based on agreements between Japan and host countries whose official languages are not English. Although the projects have occasionally used English as a tool for enhancing communications between the project officers and the local representatives (Maruyama 2006, 360 ), they have encouraged the exchange of opinions in the languages of the host countries and Japanese in order to minimise misunderstandings (Ochi 2007, 107). Some anglophone scholars have analysed Japanese-language materials in order to write about the JICA projects (Taylor 2006; Taylor 2012), but this is not common among English-speaking Japanese law experts (Sono 2001, 52), and only a handful of Japanese commentators have authored English language articles on the implications of Japanese law in the Mekong subregion (Kawashima 2019; Kaneko 2019; Teramura 2021). Therefore, when we consider factors that have contributed to the low profile of Japan's legal technical assistance in the subregion to date, the problem of language cannot be underestimated.

More recent work has begun to bridge this gap in anglophone scholarship. For example, Hai Nguyen (2019) has introduced key features of Vietnam's 2015 Civil Code (Nguyen 2019), touching upon Japan's assistance in the drafting process. Meanwhile, Trinh Nguyen (2018) has analysed specific conflict-of-laws provisions in the Code, implying that the provisions were 
inspired by Japan's Act on General Rules for Application of Laws. ${ }^{22}$ Based on his experience as advisor for the assistance projects in Vietnam, Kawashima (2019) has also offered an overview of Japan's support for drafting and amending the 2004 Civil Procedure Code. Further, Monichariya and Tanaka (2002) have offered a succinct summary of the (draft) Civil Code and Civil Procedure Code in Cambodia, which were also prepared through Japan's assistance projects. Teramura (2021) writes about rules of direct jurisdiction in Cambodia, referring to the salient influence of Japanese law in those rules. The commonality of these works is that they refer to Japanese influence, but do not directly examine the extent of that influence from Japanese legal ideas in local positive laws and practice. This points to the need for more comprehensive and systematic study of the considerable influence of Japanese private law in those countries.

\section{THE INTELLECTUAL IMPLICATIONS OF JAPANESE LAW BEYOND JAPAN}

Viewing the extension of Japanese law into the Mekong subregion as brought about by the JICA projects, and as an element of the legal pluralism in the host countries, offers both conceptual and geo-political implications for legal studies. It not only expands the conceptual horizon of Japanese law, but also provides new insights on competition between countries and institutions investing intellectual and physical resources in Vietnam, Cambodia and Laos.

\subsection{Rethinking the Concept of Japanese Law}

The practical expansion of Japanese law into the doctrinal law of the Mekong subregion then raises the question of how this might affect the way in which we conceptualise 'Japanese law' for scholarly purposes. When one undertakes the study of Japanese law, s/he first needs to think of what 'Japanese law' is. This is not a straightforward task because, as Taylor correctly points out:

"Japanese Law exists in our minds and in our writings, but it maps very imperfectly the worlds of jurisprudence and legal practice, as they exist in Japan. 'Japanese Law' is not a neutral label; it comes with built-in inferences, drawn from our own locale and from those of colleagues with whom we share the 'field'."

(Taylor 2001, 11).

Keeping this conceptual plasticity of Japanese law in mind, Nottage proposes a taxonomy with three major streams of Japanese law scholarships: 'Japanisches Recht', 'Japanese law' and 'Nihon-hö' (Nottage 2001). Nottage defines 'Japanisches Recht' as teaching and research of Japanese law in Germany, which revived impressively in the 1980s thanks to the rapid expansion of the Japanese economy as well as Japan's trade and investment links with Germany (Nottage 2001, 17). 'Japanese law' comprises of legal studies on Japanese law practiced in the English-speaking world, especially in the United States, 
Canada, Australia, New Zealand and the United Kingdom (Nottage 2001, 17-18). According to Nottage, this stream of scholarship has concentrated heavily on commercial law. Finally, 'Nihon-hö-which means Japanese law in the Japanese language-consists of "mainstream studies of Japanese law within Japan" (Nottage 2001, 19). Common to all three streams is their focus on and emphasis of legal issues within the territorial borders of Japan. In fact, a strength of 'Japanisches Recht' scholarship has been its ability to deal with black-letter texts of Japanese positive law (Nottage 2001, 17). 'Japanese law' scholarship was developed by academics who had first-hand experience in Japan (Ginsburg 2001, 32), and Sono-a leading scholar of 'Nihon-ho'comments crucially that the main concern of that stream of scholarship is the law as it is practiced in Japan, pointing out that it has been reluctant to take on the challenges of globalisation (Sono 2001, 56). ${ }^{23}$ In other words, whether they have used German, English or Japanese, the three bodies of scholarship have more or less viewed Japanese law as the phenomena taking place on the shores of Japan.

However, Taylor recommends a different vision of Japanese law, referring to the exportation of Japanese legal ideas through legal technical assistance. Taylor states:

"My own view is that we will need to rethink the field as it is constructed outside Japan, as the boxes 'Japan' and 'Japanese Law' become increasingly linked to other jurisdictions [...]. We can see this already in...the regional transfer of law through legal aid development. In short, Japan is no longer 'four main islands' of law, and 'Japanese Law' or a hybrid version of it can occur both inside and outside national boundaries."

(Taylor 2001, 13)

This conceptualisation of Japanese law has the potential to stretch the boundaries of Japanese legal ideas and usher in a paradigm shift for Japanese law sub-disciplines whose main subjects of study have tended to be the internal affairs of Japan. Assessing the influence of legal technical assistance projects on the evolution of private law in Mekong subregion will provide a venue for testing the validity of Taylor's thesis about Japanese law.

\subsection{Rethinking Geopolitical Competition among Donor Countries and Institutions}

A second implication of work on Japanese legal influence in the Mekong subregion is the potential to contribute to scholarship on geo-political competition for ODA. About 15 years ago, Taylor noted the surge in technical legal assistance provided by developed countries and global bureaucracies to transitioning economies in ASEAN (Taylor 2006). Intentionally or unintentionally, these donors compete with each other, spending on law reform projects, arguably to strengthen their audit and control in the targeted economies (Taylor 2006, 83-85). This competition has been particularly fierce in the Mekong subregion. For example, as of 2005, the law reform donor 
agencies and institutions active in Vietnam were: US Agency for International Development (USAID), AusAID, Canadian International Development Agency, Danish International Development Agency, the Swedish International Development Cooperation Agency, Maison du Droit of France, the European Union (EU), the World Bank, the Asian Development Bank (ADB) and several United Nations (UN) agencies (Edagawa 2020,7). Since then, some agencies have finished (or suspended) their projects in Vietnam, but many donors are still operating in the country, joined by a few new cooperative institutions.

According to Edagawa (2020), apart from JICA, the donor agencies that had already determined in 2020 that they would operate beyond 2021 include: Korea International Cooperation Agency, EU, Deutsche Geselleschaft fuur Internationale Zusammenarbeit, United Nations Development Programme (UNDP), United Nations Children's Fund (UNICEF), United Nations Office on Drugs and Crime (UNODC) and the World Bank (8-16). There appear to be tensions among these donors, but this has not always been the case (Takeshita 2004; Kaneko 2006, 13-14; IDPPD at JICA 2012, 39-41). From time to time, they have arguably supported each other to deal with rule-of-law issues in the Mekong subregion cooperatively. Nevertheless, the fact that many foreign agencies have been implementing law reform initiatives in the same region may imply that various countries have intersecting interests there. As one of these initiatives with complicated political backgrounds, JICA's assistance projects in the subregion are worth investigating further because JICA has distinguished itself from other donors by its respect for local sovereignty and emphasis on self-help.

\section{OPPORTUNITIES AND CHALLENGES}

New discussions on Japanese positive law's influence in the Mekong subregion offer both opportunities and challenges for practical and scholarly engagement with Japanese law in its expanding sphere of influence. In the subsections that follow, we consider how those are likely to be experienced by three stakeholder groups in particular: (i) scholars of comparative legal studies, (ii) Japanese law experts and (iii) local practitioners.

\subsection{Scholars of Comparative Legal Studies}

First, looking at the Japanese influence on legal reform in the Mekong subregion offers the comparative law community a new arena for testing the salience of existing concepts of 'legal transplants', which are part of the traditional canon for comparative law (Cairns 2013). 'Legal transplant' is a metaphoric term adapted to capture the gradual diffusion of the law or the continuous nature of the process that sometimes leads to legal change through the appropriation of foreign ideas' (Graziadei 2019, 444). ${ }^{24}$ JICA's legal technical assistance would be categorised as a legal transplantation in that it 'exports' Japanese legal models to host countries (Kitagawa 2006, 255256; Nottage 2019a, 204-207). However, normatively, scholars have argued 
that it is important that 'legal transplants' do not entail neo-imperialism or interventionist implications which (un)wittingly cause the trivialisation, if not annulment, of local customs by importing donor countries' legal models. So, for example, Kaneko claims:

"Western donors led by such influential development agencies as the World Bank and the ADB have been eager to 'transplant' particular legal models, whether common law or civil law, ... [while] Japan's [legal assistance] case offers one unique dimension to the studies on legal and judicial reforms: that is its highly respectful stance towards the local customary orders."

(Kaneko 2008, 50)

Taylor concurs, pointing out that,

"The Ministry of Justice has... aimed at not directly transplanting the Japanese national legal system, but-through repeated consultative interactions with the counterpart country-sought to effect the 'unforced legal technical assistance' suited to the needs and conditions of that country."

(Taylor 2012, 240; emphasis added)

Perspectives from comparative lawyers may be useful in understanding how the transmission of legal institutions, ideals, ideologies, doctrines and rules have been triggered by different actors with different effects (Graziadei 2019, 472), and the assistance projects in Vietnam, Cambodia and Laos are ripe for that style of analysis.

A by-product of engaging the interest of the wider comparative law academy could be improved communication and collaboration between comparative law and Japanese law scholars, which historically has been underdeveloped. For instance, Mattei has claimed that:

"Japanese law scholars discuss among themselves, rather than participate in
the general enterprise of understanding law in a comparative perspective. I
believe that such a marginalization has too high a cost for the comparative
law community." (Mattei 1997, 8)

One might argue that Mattei's statement may no longer be valid today; however, Colombo (2014) has also noted a corresponding general lack of interest in Japanese law among comparative law scholars (735-36). More recently, a group of leading European comparative legal scholars working on Japanese law stated:

"Historically,...the relationship between the legal system of Japan and those of continental Europe (especially France and Germany) has been strong. [...] It is somewhat surprising, in a globalized, predominantly English-speaking environment, to acknowledge how many Japanese law professors still devote time and energy to learn French or German (and sometimes both) to carry out what they consider proper legal research in their fields of interest. The 
situation in Europe reveals an asymmetrical attitude: Japanese law studies are conducted by a relatively restricted number of individuals who make the study of the Japanese legal system their main or at least one of their main research interests."

(Colombo et al. 2020, 5-6; emphasis added)

It is open to debate whether the cause of this asymmetry is due to the isolationism of Japanese law scholars, the Western-centric posture of comparative lawyers, or the linguistic barriers discussed earlier. ${ }^{25}$ However, new fields of study open up new possibilities. ${ }^{26}$ Since JICA's projects are explicitly schemes of legal transplantation, they fall within the research area of comparative law experts, many of whom may not yet have developed an interest in Japanese law due to being largely unaware of such projects. ${ }^{27}$ Input from Japanese law scholars will be essential to allowing comparative lawyers to deepen their understanding of the projects, given their strong grounding in both Japanese law and the languages used in vital pieces of documentation (see Section 3.3).

\subsection{Japanese Law Experts}

A second opportunity that this work presents is for Japanese law scholars to discover new audiences. At one time, Japan was the world's second-largest economy and accounted for one-sixth of the global GDP, but this is no longer the case (see World Bank n.d.). The growth in studies of the Japanese legal system in the latter half of the 20th century (e.g. von Mehren 1963; Vogel 1979; Baum 1996; Ramseyer and Nakazato 1999), and the admiration they professed, illustrated the kind of global attention that Japan was receiving at that time. The present-day Japanese economy is currently the world's thirdlargest economy with the GDP of 5.065 trillion (in 2019); however, it accounts for only one-seventeenth of global GDP, or a quarter of the US GDP (World Bank n.d.). A super-ageing society and immigration reluctance are predicted to maintain such a trajectory (Nakagawa 2019; Tomohara 2019; Burgess 2018). Thus, Japanese law should develop new dimensions in research to find new audiences. $^{28}$

\footnotetext{
25 With reference to isolationism among Japanese law scholars, Upham observes: 'Scholars of Japan[ese law]... more frequently consider themselves close intellectual colleagues of other American scholars of Japan than of other American scholars of foreign law and even within the law school world are more likely to associate intellectually with colleagues working on areas of common interest in domestic law such as corporations or legal sociology than with colleagues specializing in, e.g., French or German law' (Upham 1997, 640). It has also been widely accepted that comparative legal studies and general jurisprudence are western and anglo-American focused (Twining 2009, 10; Husa 2021, 8). While some suggest that today's comparative law scholarship is characterised by pluralism as to the kinds of legal systems compared and the methodologies adopted (van Hoecke 2017, 280; Husa 2021, 9), most scholars working within the discipline are from the West. For example, see the Notes on the Contributors in The Oxford Handbook of Comparative Law (2nd ed) (Reimann and Zimmermann 2019, xiii).

26 Note that, outside of Japan, there are several comparative law expert groups that have been working seriously to overcome the marginalisation of Japanese legal studies, including but not limited to The Australian Network for Japanese Law (ANJeL; https://www.anjel.com.au/), The Center for Japanese Legal Studies at Columbia Law School (https://jls.law.columbia.edu) and The Centre of Expertise on Japan at the Max Planck Institute for Comparative and International Private Law in Hamburg (https://www.mpipriv.de/centre-of-expertise-japan). 27 For the status of JICA's assistance projects in legal studies, see Sections 1, 2 and 3.3.

28 There are other topics that make Japan deserving of international attention. For example, see recent developments in the field of international dispute resolution (Teramura and Nottage 2018; Claxton et al. 2019, 2021).
} 


\subsection{Local Practitioners}

A third group likely to benefit from developing this new body of work is local legal experts for whom new knowledge of Japanese-inflected local law will be useful. Legal practitioners and academics working in Mekong host countries will be able to take advantage of discussion on the influence of Japanese law as an opportunity to address ambiguities in their legal systems. A key example is Cambodia, where lawyers do not perceive the doctrine of precedent (the binding nature of prior judicial decisions) as being important or convincing because judgements are not regarded as sources of law in the country-and are also not published (Teramura 2021, 202-203). ${ }^{29}$ Accordingly, lawyers in Cambodia tend to rely on authoritative sources such as official commentaries and textbooks to analyse legal questions (Teramura 2021, 203). ${ }^{30}$ Sometimes, comments on legal provisions in such texts briefly point out that the provisions are based on particular norms in Japanese law, but fall short of clarifying how Japanese legal ideas support the norms, or how the corresponding situation would be resolved under Japanese law. ${ }^{31}$ Detailed knowledge of how Japanese law has shaped Cambodian codes and laws would be useful to local legal practitioners in this context. This may prompt Cambodian lawyers facing complicated legal issues to consult relevant legal research by Japanese law experts, thereby deepening their understanding of Cambodian private law and allowing them to undertake purposive interpretation of certain articles in the codes and laws.

Of course, local experts should not be passive in debates about Japanese law's influence: input from local practitioners will be vital for assessing the compatibility of Japanese legal ideas with current legal practice in each country. ${ }^{32}$ Several years have passed since the codes and laws referenced above were finalised by local and JICA experts, and so it is likely that the legal practice of Vietnam, Cambodia and Laos surrounding those legal instruments has evolved. As a practical matter, this may have diluted the direct impact or understanding of Japanese legal concepts on local practice, while the relative weight of insights from local lawyers may have increased. Further, there may have been divergences from the original intention of the drafters, especially in the legal systems that do not strictly follow the doctrine of precedent. Hence, the time is ripe for comparative and Japanese law experts to collaborate with local experts in analysing local laws, which were established many years ago based on Japanese legal ideas but most likely have continued to evolve with local input since then.

There are rich empirical possibilities here, including discussion with local government officials and local scholars involved in law reform projects beyond those supported by JICA about how the effects of the reforms are being felt. Importantly, in these contexts neither Japanese nor comparative law scholarship can advance without local expertise and respect for local ownership of law reforms (see Sections 2 and 5.1 above).

29 Note that the courts in Vietnam and Laos do not strictly observe the doctrine of precedent either (Sakai and Kamata 2017; Ito 2020, 47).

30 This was reaffirmed in interviews with local practitioners that were conducted by the author while working as a legal consultant at a Cambodian law firm.

31 For example, see official comments on Articles 32-38 of the Cambodian Code of Civil Procedure (MOJ 2006).

32 However, private practitioners are not necessarily well positioned to take part in non-profitable research

projects. See, for example, Teramura $(2020,19)$. 


\title{
6. CONCLUSIONS
}

This article has argued that JICA's legal technical assistance projects have functioned as vehicles for exporting Japanese legal models to Vietnam, Cambodia and Laos, and that these deserve more attention from legal experts within and outside those systems, as more global audiences and stakeholders turn their eyes to the Mekong subregion. In doing so, it will be necessary to rethink the concept and reach of 'Japanese law', which promises practical and intellectual benefits to multiple legal communities. Language may be an obstacle, but it is not an insurmountable challenge. As this paper has argued, an important step for expanding Japanese law research beyond Japan will be to provide a detailed and critical overview of the assistance projects delivered in the Mekong subregion, starting with a review of relevant Japanese language documents. That research could then be followed by careful examination of Japanese law's influence on the respective private positive laws of Vietnam, Cambodia and Laos. It would be hoped that comparative legal scholars, Japanese law experts and local practitioners will individually and/or collaboratively undertake such research sooner rather than later, to assist (albeit indirectly) the Mekong subregion and ASEAN to strengthen and bolster their economies in the prolonged period of uncertainty caused by the COVID-19 pandemic-opportunities do not wait. In this way, Japanese legal studies may further extend its reach to comparative and Southeast Asian legal studies and discover new frontiers.

This kind of inquiry-Japanese law's influence in the positive laws of Vietnam, Cambodia and Laos-is likely to find some degree of hybridity: contemporary Japanese law itself is built on foreign (non-Japanese) legal concepts (Nottage 2019a, 202-04) and so legal ideas imported from Japan into the Mekong subregion can be seen as 'Japanese products', 'Western products refined in Japan' and/or 'purely Western products used in Japan'. As such, labelling all legal doctrines coming from Japan as originally or intrinsically Japanese is inaccurate (see for example Nottage 2019b, 157-59). In their reception locally, of course, influences from local legal traditions and customs should not be undervalued, as repeatedly emphasised by JICA and Japanese law experts to date. Those who consider addressing Japanese law's influence in ASEAN legal systems need to be aware of these limitations.

\section{GLOSSARY}

\section{ANJeL}

The Australian Network for Japanese Law; an Australia-based group of expert comparative legal scholars with research interests in Japanese law (https://www.anjel.com.au)

\author{
ASEAN \\ Association of Southeast Asian Nations
}


FTA

free trade agreement

GDP

gross domestic product

\section{ICCLC}

International Civil and Commercial Law Centre; satellite organisation of the International Cooperation Department of Japan's Ministry of Justice

\section{ICD}

International Cooperation Department; located within Japan's Ministry of Justice

\section{Japanisches Recht}

A stream of scholarship dedicated to the teaching and research of Japanese law in Germany (Nottage 2001, 17)

\section{JICA}

Japan International Cooperation Agency; an independent administrative institution under Japan's Ministry of Foreign Affairs

\section{Mekong Subregion (of ASEAN)}

Comprised of the countries that are located along the Mekong River: Vietnam, Cambodia, Laos, Myanmar and Thailand (Ho and Pitakdumrongkit 2019)

\section{MOFA}

Ministry of Foreign Affairs (Japan)

MOJ

Ministry of Justice (Japan)

\section{Nihon-hō [日本法]}

lit., 'Japanese law'; a stream of scholarship consisting of "mainstream studies of Japanese law within Japan" (Nottage 2001, 19)

\section{ODA}

official development assistance; Japan's national official development assistance agency is Japan International Cooperation Agency

\section{SG}

Study Group (for the Cambodian Civil Code); a group of Cambodia legal elites established within the Cambodian Ministry of Justice to review drafts of the Cambodian Civil Code

\section{WG}

Working Group (for the Cambodian Civil Code); a group of leading Japanese legal scholars who worked under the Japan International Cooperation Agency to draft the Civil Code of Cambodia 


\section{REFERENCES}

Amarthalingam, S. 2020. "Against the Odds-Is Cambodia a Weak Link to ASEAN's Global Supply Chain?" The Phonon Penh Post, 27 August. Accessed 14 July, 2021. https://www.phnompenhpost.com/special-reports/against-odds-cam bodia-weak-link-aseans-global-supply-chain.

Arcibal, C. 2021. "Laos Tipped to Be the 'Next Cambodia' as Relaxed Rules for Foreign Homebuyers Can Make It a Property Investment Hotspot." South China Morning Post, 2 March. Accessed 14 July, 2021. https://www.scmp. com/business/article/3123645/laos-tipped-be-next-cambodia-relaxedrules-foreign-homebuyers-can-make-it.

Baum, H., ed. 1996. Japan: Economic Success and Legal System. Berlin and New York: De Gruyter. https://doi.org/10.1515/9783110908886.

Beer, L. W., and H. Tomatsu. 1978. "A Guide to the Study of Japanese Law." Occasional Papers/Reprints Series in Contemporary Asian Studies 7 (19): 1-52.

Boudreau, J. and D. T. U. Nguyen. 2020. "Rural Vietnam Booms With Jobs From Apple-Led Move in Supply Chains." Bloomberg, 26 October. Accessed 5 July, 2021. https://www.bloomberg.com/news/newsletters/2020-10-26/supply-chains -latest-apple-shift-means-boom-in-rural-vietnam.

Burgess, C. 2018. "Genuine Immigration Reform Still Alien to Japan." East Asia Forum, 15 November. Accessed 14 July, 2021. https://www.eastasia forum.org/2018/11/15/genuine-immigration-still-alien-to-japan/.

Cairns, J. W. 2013. "Watson, Walton, and the History of Legal Transplants." Georgia Journal of International and Comparative Law 41: 637-96.

Chheng, K. 2020. "Cambodia's Political and Economic Response to COVID-19." East Asia Forum, 8 May. https://www.eastasiaforum.org/2020/05/08/ cambodias-political-and-economic-response-to-covid-19/.

Claxton, J., L. Nottage and N. Teramura. 2019. “Developing Japan as a Regional Hub for International Dispute Resolution: Dream Come True or Daydream?” Journal of Japanese Law 24 (47): 109-31.

. 2021. "Disruption as a Catalyst for International Dispute Services in Japan: No Longer Business as Usual?" In New Frontiers in Asia-Pacific International Arbitration and Dispute Resolution, edited by L. Nottage, S.Ali, B. Jetin and N. Teramura, 237-60. Alphen aan den Rijn: Wolters Kluwer.

Colombo, G. F.. 2014. "Japan as a Victim of Comparative Law." Michigan State International Law Review 22 (3): 731-53.

Colombo, G. F., B. Jaluzot, W. Ben-Sade, R. Greatrex, F. Barberán, D. Vanoverbeke, L. S. Cinelli, H. Baum and M. Bälz. 2020. "The State of Japanese Legal Studies in Europe.” Journal of Japanese Law 25 (49): 5-46.

Dahles, H. 2020. "China's Post-COVID-19 Woes to Flow through the Mekong." East Asia Forum, 15 April. Accessed 5 July, 2021. https://www.eastasiaforum. org/2020/04/15/chinas-post-covid-19-woes-to-flow-through-the-mekong/. 
Department of Health, Australia. 2021. "Total COVID-19 Cases in Australia by Source of Infection.” Australian Government Department of Health. Accessed 30 June, 2021. https://www.health.gov.au/news/health-alerts/novel-corona virus-2019-ncov-health-alert/coronavirus-covid-19-case-numbers-andstatistics\#total-covid19-cases-in-australia-by-source-of-infection.

Duong, M. C.. 2020a. “The Impacts of COVID-19 on Vietnam and Ways to Move Forward." East Asia Forum, 9 June. Accessed 5 July, 2021. https://www. eastasiaforum.org/2020/06/09/the-impacts-of-covid-19-on-vietnam-andways-to-move-forward/.

2020b. “Mass Masking and Vietnam's COVID-19 Success.” East Asia Forum, 23 October. Accessed 14 July, 2021. https://www.eastasiaforum.org/2020/ 10/23/mass-masking-and-vietnams-covid-19-success/.

Edagawa, M. 2020. “The Major Development Aid Agencies Providing Vietnam with Legal and Judicial Technical Assistance [in Japanese].” ICD News (84): 6-18.

Elliot, L. 2021. "China Reports Strongest Growth in Two Years after Covid-19 Recovery." The Guardian, 18 January. Accessed 5 July, 2021. https://www. theguardian.com/world/2021/jan/18/china-growth-covid-19-coronaviruspandemic.

European Commission. 2020. "Commission Decides to Partially Withdraw Cambodia's Preferential Access to the EU Market." European Commission. 12 February. Accessed 10 February, 2021. https://trade.ec.europa.eu/doclib/ press/index.cfm?id=2113.

Forsaith, C. 2016. "Cambodia." In Investment Protection in Southeast Asia: A Country-by-Country Guide on Arbitration Laws and Bilateral Investment Treaties, edited by L. Malintoppi and C. Tan, 73-108. Leiden: Brill. https:// doi.org/10.1163/9789004335257_005.

Ginsburg, T. 2001. “In Defense of “Japanese Law.” Journal of Japanese Law 6 (12): 27-35.

2010. “Studying Japanese Law Because It's There." The American Journal of Comparative Law 58 (1): 15-26. https://doi.org/10.5131/ajcl.2009.0002.

Givens, S. 2013. “The Vagaries of Vagueness: An Essay on 'Cultural' vs. 'Institutional' Approaches to Japanese Law.” Michigan State International Law Review 22 (3): 839-78.

Graziadei, M. 2019. “Comparative Law, Transplants, and Receptions.” In Comparative Law, Transplants, and Receptions, edited by M. Reimann and R. Zimmermann, 443-73. New York and London: Oxford University Press. https://doi.org/10.1093/oxfordhb/9780198810230.013.14.

Haley, J. O. 2010. "Why Study Japanese Law?" The American Journal of Comparative Law 58 (1): 1-14. https://doi.org/10.5131/ajcl.2009.0001.

Harrington, N. 2016. “Lao People's Democratic Republic." In Investment Protection in Southeast Asia: A Country-by-Country Guide on Arbitration Laws and Bilateral Investment Treaties, edited by L. Malintoppi and C. Tan, 161-99. Leiden: Brill. https://doi.org/10.1163/9789004335257_007. 
Ho, S. and K. Pitakdumrongkit. 2019. "Can ASEAN Play a Greater Role in the Mekong Subregion?” The Diplomat, 20 January. Acessed 5 February, 2021. https://thediplomat.com/2019/01/can-asean-play-a-greater-role-in-themekong-subregion/.

Husa, J. 2021. "Comparative Law, Literature and Imagination: Transplanting Law into Works of Fiction." Maastricht Journal of European and Comparative Law XX (X): 1-19. https://doi.org/10.1177/1023263X21995337.

ICD (International Cooperation Department). 2020. International Cooperation Department: Ministry of Justice Research and Training Institute. Tokyo: International Cooperation Department. https://www.moj.go.jp/content/00 1317045.pdf.

IDPPD (Industrial Development and Public Policy Department) at JICA. 2012. Kanbojia ni okeru hōseibi shien no kiseki-Minpō minji soshō-hō tō kisō shien no kei'i to hōhōron [カンボジアにおける法整備支援の軌跡一民法・民事 訴訟法等起草支援の経緯と方法論一]. https://openjicareport.jica.go.jp/pdf/ 12066494.pdf.

Irie, K. 2020. “The Legislative History of the Civil Code of Laos [in Japanese].” ICD News (84): 65-121.

Ito, A. 2020. "Raosu no hōgaku kyōiku to hōsō yōsei kenshū no genjō to kadai-Raosu hōgaku no tanjō wo mezashite [ラオスの法学教育と法曹養成研修の現状と課題 〜ラオス法学の誕生を目指して〜]" ICD News (82): 40-51.

JICA (Japan International Cooperation Agency). n.d. "Materials." Japan International Cooperation Agency. Tokyo: JICA. Accessed 12 February, 2021. https://www. jica.go.jp/project/english/cambodia/0701047/materials/index.html.

. 2009. "JICA's Vision." Japan International Cooperation Agency. Tokyo: JICA. Accessed 5 February, 2021. https://www.jica.go.jp/english/about/ mission/index.html.

. 2014. JICA's Cooperation for Rule of Law Promotion. Tokyo: JICA. Accessed 5 February, 2021. https://www.jica.go.jp/english/publications/ brochures/c8h0vm0000avs7w2-att/JICAsCooperationforRuleofLawPro motion.pdf.

Kaneko, Y. 2006. Hōseibi shien ni okeru seisaku handan ni shisuru ritsuan hyōka shuhō no kentō [法整備支援における政策判断に資寸る立案·評価手法の検討]. Tokyo: Institute For International Cooperation at JICA.

2008. "Catalistic Role of Legal Assistance between Formal Law and Social Norms: Hints from Japanese Assistance." Journal of International Cooperation Studies 15 (3): 49-68.

2010. "A Procedural Approach to Judicial Reform in Asia: Implications from Japanese Involvement in Vietnam." Columbia Journal of Asian Law 23 (2): 313-55. 
Asia: Beyond Western Capitalism, edited by Y. Kaneko, 155-76. Singapore: Springer. https://doi.org/10.1007/978-981-13-6203-3_8.

Kawashima, S. 2019. "One Aspect of Civil Procedure Reform in Asia: Placing the Focus upon Vietnam." In Civil Law Reforms in Post-Colonial Asia: Beyond Western Capitalism, edited by Y. Kaneko, 101-29. Singapore: Springer. https://doi.org/10.1007/978-981-13-6203-3_6.

Keola, S. 2021. "What Next for Laos' Growth Strategy?" East Asia Forum, 15 January. Accessed 5 February, 2021. https://www.eastasiaforum.org/2021/01/15/ what-next-for-laos-growth-strategy/.

Kischel, U. 2019. Comparative Law. Oxford: Oxford University Press. https://doi. org/10.1093/oso/9780198791355.001.0001.

Kitagawa, Z. 2006. “Development of Comparative Law in East Asia." In The Oxford Handbook of Comparative Law, edited by M. Reimann and R. Zimmermann, 238-59. New York and London: Oxford University Press. https://doi. org/10.1093/oxfordhb/9780199296064.013.0008.

KPMG. 2020. Investing in Cambodia: Seize the Opportunity-2020 and Beyond. Accessed 10 February, 2021. https://home.kpmg/content/dam/kpmg/kh/ pdf/publication/2020/investing-in-cambodia-2020-and-beyond-kpmg-kh.pdf.

Kuong, T. 2018. "Legal Assistance in the Japanese ODA: The Spark of a New Era." Asian Journal of Law and Society 5 (2): 271-87. https://doi.org/10.1017/ als.2018.31.

Lancaster, C. 2010. "Japan's ODA: Naiatsu and Gaiatsu-Domestic Sources and Transnational Influences." In Japanese Aid and the Construction of Global Development: Inescapable Solutions, edited by D. Leheny and K. Warren, 29-53. London and New York: Routledge.

Lei, C. 2012. "Contextualising Legal Transplant: China and Hong Kong." In Methods of Comparative Law, edited by P. G. Monateri, 192-209. Cheltenham: Edward Elgar Publishing.

Leung, S. 2020. "Vietnam's Economy Weathers the COVID-19 Storm-Good Policy or Luck?” East Asia Forum, 6 October. Accessed 10 February, 2021. https:// www.eastasiaforum.org/2020/10/06/vietnams-economy-weathers-thecovid-19-storm-good-policy-or-luck/.

Levin, M. A. and K. Hiraoka. 2020. "Gender and Law Scholarship in the Law in Japan Field: A Comprehensive Bibliographic Study.” Asian-Pacific Law \& Policy Journal 21 (2): 1-22.

Maruyama, T. 2006. "Hōmushō hōmu sōgō kenkyūjo ni yoru hōseibi shien e no torikumi [法務省法務総合研究所による法整備支援一の取組多].” Keio Law Journal (5): 351-63.

Master, F., O. Sriring and A. M. Roantree. 2018. "Supply Chain Reaction: Trade War Refugees Race to Relocate to Vietnam, Thailand." Reuters, 29 November. Accessed 5 February, 2021. https://www.reuters.com/article/us-usa-trade-

(1)


china-vietnam/supply-chain-reaction-trade-war-refugees-race-to-relocateto-vietnam-thailand-idUSKCN1NX2XZ.

Mattei, U. 1997. "Three Patterns of Law: Taxonomy and Change in the World's Legal Systems." The American Journal of Comparative Law 45 (1): 5-44. https://doi.org/10.2307/840958.

Melwani, V. 2016. "Vietnam." In Investment Protection in Southeast Asia: A Country-by-Country Guide on Arbitration Laws and Bilateral Investment Treaties, edited by L. Malintoppi and C. Tan, 415-45. Leiden: Brill. https:// doi.org/10.1163/9789004335257_014.

MOFA (Ministry of Foreign Affairs of Japan). 1992. “Japan’s Official Development Assistance Charter". Ministry of Foreign Affairs of Japan. Cabinet Decisions, 30 June. Accessed 12 July, 2021. https://www.mofa.go.jp/policy/oda/ summary/1999/ref1.html.

.1994. "History of Official Development Assistance". Ministry of Foreign Affairs of Japan. Accessed 12 July, 2021. https://www.mofa.go.jp/policy/oda/ summary/1994/1.html.

2003. Japan's Official Development Assistance Charter. 29 August. Accessed 12 July, 2021. https://www.mofa.go.jp/policy/oda/reform/revision0308.pdf.

.2015. Cabinet Decision on the Development Cooperation Charter. 10 February. Accessed 12 July, 2021. https://www.mofa.go.jp/files/000067701. pdf.

MOJ (Ministry of Justice, Japan). n.d.[a]. “Kokusai kyōryoku-bu ni yoru hōseido seibi shien katsudō-sekai ni kōken, Nihon no chikara! [国際協力部による法制度 整備支援活動 ～世界に貢献, 日本の力!].” Ministry of Justice [法務省]. Accessed 12 February, 2021. https://www.moj.go.jp/housouken/houso_lta_ lta.html.

.n.d.[b] "Legal Technical Assistance Activities by the International Cooperation Department Contributing to the World is Japan's Strength! .” Ministry of Justice. Accessed 19 March, 2021. http://www.moj.go.jp/EN/ housouken/houso_lta_lta.html.

.2006. “Kanbojia ōkoku Minji soshō hōten [カンボジア王国民事訴訟法典]”. Ministry of Justice [法務省]. Accessed February 10, 2021. http://www.moj. go.jp/content/000122392.pdf.

2021. "Cambodia: Activities and Achievements [in Japanese]." Accessed 19 August 2021. https://www.moj.go.jp/housouken/houso_houkoku_cambo.html.

Monichariya, M. and K. Tanaka. 2002. "Drafting a New Civil Code and Code of Civil Procedure in Cambodia with Japanese Technical Assistance." Uniform Law Review 7 (4): 1047-59. https://doi.org/10.1093/ulr/7.4.1047.

Morishima, A. 2003. “Kanbojia minpō sōan no kisō shien jigyō ni tazusawatte [カンボ ジア民法草案の起草支援事業に携わって].” ICD News (11): 4-8. 
Nakagawa, M. 2019. “Japan Is Aging Faster than We Think.” East Asia Forum, 17 October. https://www.eastasiaforum.org/2019/10/17/japan-is-aging-fasterthan-we-think/.

Nguyen, H. H. 2019. "A Study on the Civil Code Revision: The 2015 Civil Code of Vietnam." In Civil Law Reforms in Post-Colonial Asia: Beyond Western Capitalism, edited by Y. Kaneko, 85-100. Singapore: Springer. https://doi. org/10.1007/978-981-13-6203-3_5.

Nguyen, T. H. T. 2018. "Party Autonomy in Vietnam-The New Choice of Law Rules for International Contracts in the Civil Code 2015." Journal of Private International Law 14 (2): 343-67. https://doi.org/10.1080/17441048.2018.150 7984.

Nicholson, P. and S. Hinderling. 2013. "Japanese Aid in Comparative Perspective." Hague Journal on the Rule of Law 5 (2): 274-309. https://doi.org/10.1017/ S1876404512001157.

Nicholson, P. and T. Kuong. 2014. "Japanese Legal Assistance: An East Asian Model of Legal Assistance and Rule of Law?" Hague Journal on the Rule of Law 6 (2): 141-77. https://doi.org/10.1017/S1876404514001079.

Nicholson, P. and S. Low. 2013. "Local Accounts of Rule of Law Aid: Implications for Donors." Hague Journal on the Rule of Law 5 (1): 1-43. https://doi. org/10.1017/S1876404512001017.

Nottage, L. 2001. "Japanisches Recht, Japanese Law, and Nihon-hō: Towards New Transnational Collaboration in Research and Teaching." Journal of Japanese Law 6 (12): 17-21.

. 2019a. "The Development of Comparative Law in Japan." In The Oxford Handbook of Comparative Law, edited by M. Reimann and R. Zimmermann, 202-26. New York and London: Oxford University Press.

. 2019b. "Product Safety Law: Fragmented Regulation and Emergent Product Liability Regimes." In ASEAN Consumer Law Harmonisation and Cooperation: Achievements and Challenges, edited by L. Nottage, J. Malbon, J. Paterson and C. Beaton-Wells, 122-204. Cambridge: Cambridge University Press.

Ochi, M. 2007. "Wagakuni no hōseibi shien no genjō to mondai-ten-hōbunya kara no heiwa kōchiku [我が国の法整備支援の現状と問題点一法分野からの平和構 築一].” The Reference [レファレンス] 57 (3): 99-109.

OECD (Organisation for Economic Co-operation and Development). 2017. "Trends in Foreign Investment and Trade in Lao PDR." In OECD Investment Policy Reviews: Lao PDR, edited by OECD, 51-65. Paris: OECD Publishing. https://doi.org/10.1787/9789264276055-6-en.

Phallack, K. 2012. "Overview of the Cambodian Legal and Judicial System and Recent Efforts at Legal and Judicial Reform." In Introduction to Cambodian Law, edited by H. Peng, K. Phallack and J. Menzel, 5-22. Phnom Penh: Konrad-Adenauer-Stiftung.

\author{
(1)
}


Phea, K. 2020. "Cambodia-China Relations in the New Decade." Diplomatic Briefing 1: $20-25$.

Post Staff. 2021. "Restrictions Re-imposed in Capital as Covid Cases Surge." The Phnom Penh Post, 2 June. Accessed 5 July, 2021.https://www.phnompenhpost. $\mathrm{com} /$ national/restrictions-re-imposed-capital-covid-cases-surge.

Primiano, C. and S. Po. 2020. "Cambodia Holds China Close Despite Coronavirus." East Asia Forum, 13 March. Accessed 14 July, 2021. https://www.eastasia forum.org/2020/03/13/cambodia-holds-china-close-despite-coronavirus/.

Ramseyer, M. J., and M. Nakazato. 1999. Japanese Law: An Economic Approach. Chicago: University of Chicago Press.

Reed, J. 2020. "Vietnam Prepares for Supply Chain Shift from China." Financial Times, 28 December. Accessed 10 February, 2021. https://www.ft.com/ content/e855b706-e431-4fc5-9b0a-05d93balbcbe.

Reimann, M. and R. Zimmermann, eds. 2019. The Oxford Handbook of Comparative Law. New York and London: Oxford University Press. https://doi.org/10.1093/ oxfordhb/9780198810230.001.0001.

Reuters Staff. 2020. "Cambodia PM Says Ruling Party to Dominate Politics for up to 100 Years.” Reuters, 22 June. Accessed 14 July, 2021. https://www.reuters. com/article/us-cambodia-politics-idUSKBN23T0TO.

Ross, N., A. Apps and S. Campbell. 2016. "Shaping the Future Lawyer: Connecting Students with Clients in First-Year Law." In Legal Education: Simulation in Theory and Practice, edited by C. Strevens, R. Grimes and E. Phillips, 67-85. London and New York: Routledge.

Sakai, N. and S. Kamata. 2017. “The Doctrine of Precedent in Vietnam.” ICD News (73): 29-40.

Sakano, I. 2003. “Kanbojia minpō minji soshō-hō kisō shien ni kakawatte [カンボディ ア民法・民事訴訟法起草支援に関わって].” ICD News (7): 91-98.

. 2021. "Kanbojia hōseibi shien ni okeru tayō na kadai-bibō mo kanete [力 ンボジア法制度整備支援における多様な課題〜備忘も兼ねて].” ICD News (87): 57-63.

Schraeder, P. J., S. W. Hook and B. Taylor. 1998. "Clarifying the Foreign Aid Puzzle: A Comparison of American, Japanese, French, and Swedish Aid Flows." World Politics 50 (2): 294-323. https://doi.org/10.1017/S0043887100008121.

Siems, M. 2019. "The Power of Comparative Law: What Types of Units Can Comparative Law Compare." American Journal of Comparative Law 67 (4): 861-88. https://doi.org/10.1093/ajcl/avz030.

Sims, K. 2020. "Laos Set Its Own Debt Trap." East Asia Forum, 31 October. Accessed 5 February, 2021. https://www.eastasiaforum.org/2020/10/31/laos-set-itsown-debt-trap/. 
Sono, H. 2001. "The Multiple Worlds of 'Nihon-hö'." Journal of Japanese Law 6 (12): $50-59$.

Swiss Re Institute. 2020. "De-risking Global Supply Chains: Rebalancing to Strengthen Resilience." Swiss Re Institute, 11 September. Accessed 10 February, 2021. https://www.swissre.com/institute/research/sigma-research /sigma-2020-06.html.

Takeshita, M. 2003. “Kanbojia ni okeru donākan kyōryoku no kadai [カンボジアにお けるドナー間協力の課題].” ICD News (9): 25-32.

.2004. "Challenges for Inter-donor Cooperation in Cambodia [in Japanese]." ICD News (14): 24-30.

Tamura, S. 2019. "The Role of the Japanese Civil Code in the Codification in the Kingdom of Siam." In Civil Law Reforms in Post-Colonical Asia: Beyond Western Capitalism, edited by Y. Kaneko, 53-70. Singapore: Springer. https:// doi.org/10.1007/978-981-13-6203-3_3.

Taylor, V. 2001. "Spectres of Comparison: Japanese Law through Multiple Lenses." Journal of Japanese Law 6 (12): 11-16.

. 2005. "New Markets, New Commodity: Japanese Legal Technical Assistance." Wisconsin International Law Journal 23 (2): 251-82.

. 2006. "The Law Reform Olympics: Measuring the Effects of Law Reform in Transitional Economies." In Law Reform in Developing and Transitional States, edited by T. Lindsey, 83-105. London and New York: Routledge.

. 2009. "Rule-of-Law Assistance Discourse and Practice: Japanese Inflections." In Law in the Pursuit of Development Principles into Practice?, edited by A. P. Kessaris, 161-79. Abingdon: Routledge-Cavendish.

. 2012. “Japan's Legal Technical Assistance: A Different Modernization Narrative?" In Legitimacy, Legal Development and Change: Law and Modernization Reconsidered, edited by D. K. Linnan, 235-49. Abingdon and New York: Routledge.

Teramura, N. 2020. Ex Aequo et Bono as a Response to the 'Over-Judicialisation'of International Commercial Arbitration. Alphen aan den Rijn: Wolters Kluwer.

2021. "Cambodia." In Direct Jurisdiction, edited by A. Reyes and W. Lui. Oxford, New York and London: Hart Publishing.

Teramura, N., S. F. Ali and A. Reyes. 2021. "Expanding Asia-Pacific Frontiers for International Dispute Resolution: Conclusions and Recommendations." In New Frontiers in Asia-Pacific International Arbitration and Dispute Resolution, edited by L. Nottage, S. F. Ali, B. Jetin and N. Teramura, 355-68. Alphen aan den Rijn: Wolters Kluwer. https://doi.org/10.2139/ssrn.3640111.

Teramura, N. and L. Nottage. 2018. "Japan's (In)Capacity in International Commercial Arbitration." Kluwer Arbitration Blog, 17 November. Accessed 5 February, 2021. http://arbitrationblog.kluwerarbitration.com/2018/11/17/ japans-incapacity-international-commercial-arbitration/. 
Thul, P. C. 2020. "China, Cambodia Clinch Free Trade Pact in under a Year." Reuters, 12 October. Accessed 5 February, 2021. https://www.reuters.com/article/uschina-cambodia-fta-idUSKBN26X0XB.

Tomohara, A. 2019. “Securing Japan's FDI Future.” East Asia Forum, 25 October. Accessed 14 February, 2021. https://www.eastasiaforum.org/2019/10/25/ securing-japans-fdi-future/.

Transparency International. 2021. Corruption Perception Index 2020. Accessed 1 June, 2021. https://www.transparency.org/en/cpi/2020/index/nzl.

Twining, W. 2009. General Jurisprudence: Understanding Law from a Global Perspective. Cambridge: Cambridge University Press. https://doi.org/10.1017/ CBO9780511807374.

Upham, F. K. 1997. "The Place of Japanese Legal Studies in American Comparative Law." Utah Law Review 1997 (2): 639-56.

US Department of State. 2020a. "2020 Investment Climate Statements: Cambodia.” US Department of State. Accessed 11 February, 2021. https://www.state.gov/ reports/2020-investment-climate-statements/cambodia/.

. 2020b. "2020 Investment Climate Statements: Laos." US Department of State. Accessed 11 February, 2021. https://www.state.gov/reports/2020investment-climate-statements/laos/.

. 2020c. "2020 Investment Climate Statements: Vietnam." US Department of State. Accessed 11 February. https://www.state.gov/reports/2020investment-climate-statements/vietnam/.

van Hoecke, M. 2017. "Is There Now A Comparative Legal Scholarship?" Journal of Comparative Law 12 (1): 271-80.

Vogel, E. F. 1979. Japan as Number One: Lessons for America. Cambridge: Harvard University Press. https://doi.org/10.4159/harvard.9780674366299.

von Mehren, A. Taylor, ed. 1963. Law in Japan: The Legal Order in a Changing Society. Cambridge: Harvard University Press. https://doi.org/10.4159/ harvard.9780674593336.

Walsh, J., T. Q. Nguyen and B. Schrage. 2021. "Time to Upgrade Corporate Governance in Vietnam." East Asia Forum, 27 May. Accessed 14 July, 2021. https://www.eastasiaforum.org/2021/05/27/time-to-upgrade-corporategovernance-in-vietnam/.

Watson, A. 1974. Legal Transplants: An Approach to Comparative Law. Charlottesville: The University Press of Virginia.

West, L. and T. Q. Leong. 2019. "Assessing the State of the Rule of Law in South East Asia." State of the Neighbourhood 2: 57-68.

WHO (World Health Organization). 2021a. "Cambodia." WHO Coronavirus (COVID-19) Dashboard. Accessed 5 July, 2021. https://covid19.who.int/ region/wpro/country/kh.

(1)


. 2021b. "COVID-19 in Cambodia". World Health Organization. Accessed 19 March, 2021. https://www.who.int/cambodia/emergencies/covid-19-responsein-cambodia.

2021c. "Laos." WHO Coronavirus (COVID-19) Dashboard. Accessed 5 July, 2021. https://covid19.who.int/region/wpro/country/la.

2021d. "Vietnam." WHO Coronavirus (COVID-19) Dashboard. Accessed 5 July, 2021. https://covid19.who.int/region/wpro/country/vn.

World Bank, The. n.d. "GDP (current US\$)-Japan." The World Bank. Accessed 12 February, 2021. https://data.worldbank.org/indicator/NY.GDP.MKTP. CD?locations=JP.

2020. From COVID-19 to Climate Change: How Vietnam can become the Champion of Green Recovery. Washington DC: World Bank. Accessed 5 February, 2021. https://documents1.worldbank.org/curated/en/52142160798 1204344/pdf/Taking-Stock-From-COVID-19-to-Climate-Change-HowVietnam-Can-Become-the-Champion-of-Green-Recovery.pdf.

.2021a. "The World Bank in Cambodia." The World Bank. Last Modified 14 April, 2021. Accessed 14 July, 2021. https://www.worldbank.org/en/ country/cambodia/overview.

.2021b. "The World Bank in Lao PDR." The World Bank. Last Modified 6 April, 2021. Accessed 14 July, 2021. https://www.worldbank.org/en/ country/lao/overview.

.2021c. "The World Bank In Vietnam." The World Bank. Last Modified 7 April, 2021. Accessed 6 June, 2021. https://www.worldbank.org/en/country/ vietnam/overview.

.2021d. "World Bank Open Data: Free and Open Access to Global Development Data." The World Bank. Accessed 6 June, 2021. https://ata. worldbank.org.

World Justice Project. 2020. Rule of Law Index 2020. Accessed 5 February, 2021. https://worldjusticeproject.org/sites/default/files/documents/WJP-ROLI2020-Online_0.pdf.

Yamada, M. 2001. "Legal Technical Assistance in Japan's ODA: An Implication for Law and Development." Proceedings of the Roundtable Meeting: Law, Development and Socio-Economic Changes in Asia, Manila, the Philippines. Chiba, Japan: Institute of Developing Economies, Japan External Trade Organization (IDE-JETRO).

Zhou, C. 2021. "US-China Trade War Hits Third Anniversary, with No Sign of Joe Biden Easing Economic Pressure." South China Morning Post, 6 July. Accessed 14 July, 2021. https://www.scmp.com/economy/china-economy/article/314 0047/us-china-trade-war-hits-third-anniversary-no-sign-biden. 